\title{
A WORD ABOUT WORDS
}

In the pages that follow, I will only use one name for the Vietnamese state that went to war against the French (and then against the Americans). It is the "Democratic Republic of Vietnam," abbreviated as the DRV. In Vietnamese it is: Viet Nam Dan Chu Cong Hoa. This term refers to the state Ho Chi Minh declared independent on 2 September 1945 and which he led as President until an armistice was signed in Geneva on 21 July 1954, ending the fighting and my book. I do not use the term "Viet Minh" or the "Viet Minh regime" to describe this state or its activities. For one, the Viet Minh ceased to exist in early 1951, intentionally dissolved by its communist makers. That is reason enough not to use it after that date. Second, the "Viet Minh" was a nationalist front created in 1941, briefly a political party in 1945 and 1946, but it was never a state. To treat it as if it were is not only inaccurate; but it also prevents us from seeing a more complicated and, I believe, more interesting story of statecraft during the Indochina War, the subject of this book.

We also need to agree on the terms we use to describe what the French and their Vietnamese partners were doing. First, I use the terms "French Indochina" or the "Indochinese federation" to refer to the colonial state the French stitched back together in one form or another between 1945 and 1954. The French folded their Indochinese federation into a larger colonial entity known as the French Union, which was created in October 1946 and based out of Paris. ${ }^{1}$ To this, we need to add the "Associated State of Vietnam." It came to life when the French finally allowed their noncommunist Vietnamese partners lined up behind the former Emperor Bao Dai to combine Cochinchina, Annam, and Tonkin 
(for the colonial south, center, and north) into a unified territorial state the French agreed to call "Vietnam." This Vietnamese state was nevertheless part of an Indochinese ensemble known officially as the Etats associés de l'Indochine or the "Associated States of Indochina." It included Bao Dai's Vietnam, King Sisavang Vong's Laos, and King Norodom Sihanouk's Cambodia. All three states were by "association" part of an Indochinese federal state run by the French. It was not the "State of Vietnam." It was the "Associated State of Vietnam." Collectively, the "Associated States of Indochina" were, in turn, part of this larger imperial body administered from Paris, the French Union. The Vietnamese allied with the French knew that "Association" at both the Indochinese and French Union levels bound them legally to the French republic.

A further word on Bao Dai's Vietnam is necessary here. Official historians in communist Vietnam today, the one Ho declared independent in 1945, have preferred to banish the Associated State of Vietnam from their historical memory. ${ }^{2}$ Starting in 1949, Ho Chi Minh's disciples dismissed it as a "puppet regime" (che do bu nhin or nguy) and its leaders as the "lackeys" (tay sai) of the French, not least of all its head of state, the ex-emperor Bao Dai. The problem is that Bao Dai's Associated State of Vietnam existed at the time. It is not because it was not fully sovereign that it does not matter. Bao Dai's Vietnam and the French Indochinese federation standing behind it were actors with whom Ho Chi Minh had to contend in order to build the Democratic Republic of Vietnam. The same is true of the two sister states Ho Chi Minh brought to life in Laos and Cambodia during the second half of the Indochina conflict, discussed later in this book. Although they were not sovereign states, free of Vietnamese control, that does not mean that they do not matter. They run Laos and Cambodia to this day.

Words count, and by using them precisely and carefully they can help us to shed new light on the complexity of the Democratic Republic of Vietnam, as well as the other states involved in the Indochina War. Having said all of this, there will admittedly be times when I use the words "Vietnam" and "the Vietnamese" to refer in general terms to Ho Chi Minh's Vietnam or to the one Bao Dai led in association with the French. Readers should not interpret this as political bias, but rather as a desire 
to keep the narrative moving. I do not want to burden my readers with all sorts of qualifications. For similar reasons, I will also speak from time to time of "Vietnamese communists" and "French colonialists." I justify this usage on the following grounds: at the core of the Democratic Republic of Vietnam was the Communist Party and its founder, Ho Chi Minh. No matter how anticolonialist Ho and his entourage most certainly were, they were also dedicated communists. Similarly, those in charge of the French republic during the Indochina War, with the possible exception of the communists from 1948, wanted to keep Vietnam French, in the French Union, and this straight through until the Geneva Conference. Again, no matter how anticommunist many French leaders were, they were the colonizers during the Indochina War. It was no accident that the French went to war in Algeria a few months after Dien Bien Phu fell in May 1954. It was not to stop communists. 
